\title{
KEPRIBADIAN TOKOH UTAMA DALAM NOVEL RINDU KARYA TERE LIYE: SEBUAH KAJIAN PSIKOLOGI SASTRA
}

\author{
Imas Juidah \\ Program Studi Pendidikan Bahasa dan Sastra Indonesia \\ Universitas Wiralodra
}

Email: imas.juidah@unwir.ac.id

\begin{abstract}
ABSTRAK
Penelitian ini bertujuan untuk mendeskripsikan: (1) perjuangan menuju superior yang dilakukan tokoh utama novel Rindu karya Tere Liye, (2) pengamatan subjektif terhadap tokoh utama novel Rindu karya Tere Liye, (3) kesatuan kepribadian tokoh utama novel Rindu karya Tere Liye, (4) minat sosial tokoh utama novel Rindu karya Tere Liye, (5) gaya hidup tokoh utama novel Rindu karya Tere Liye, dan (6) kekuatan kreatif tokoh utama novel Rindu karya Tere Liye. Penelitian ini merupakan penelitian deskriptif kualitatif. Data dalam penelitian ini adalah kata-kata, kalimat, dan kutipan yang terdapat dalam novel Rindu. Sedangkan, sumber data dalam penelitian ini adalah novel Rindu karya Tere Liye yang diterbitkan oleh Republika Penerbit pada tahun 2014 sebanyak 544 lembar. Teknik pengumpulan data dalam penelitian ini adalah teknik baca dan catat. Hasil penelitian menunjukkan bahwa terdapat enam teori kepribadian pada tokoh utama yaitu tokoh Ahmad Karaeng atau Gurutta. Pertama, Perjuangan menjadi superior (striving for superiority) yang terdapat pada tokoh Gurutta dalam novel Rindu karya Tere Liye, meliputi perjuangan Gurutta dalam menggapai cita-citanya dengan memanfaatkan masa mudanya untuk belajar agama di Aceh dan Yaman. Kedua, pengamatan subjektif (subjective perceptions) yang terdapat pada tokoh Gurutta dalam novel Rindu karya Tere Liye adalah Gurutta selalu dapat menasihati dan memberikan motivasi kepada orang lain. Menurut pengamatan orang-orang di sekelilingnya, Gurutta adalah seorang ulama yang terkenal di Makassar, beradab, berilmu, dihormati, dan dicintai banyak orang karena tinggi budinya. Ketiga, kesatuan kepribadian (unity of personality) yang terdapat pada tokoh Gurutta dalam novel Rindu karya Tere Liye adalah Gurutta memiliki kepribadian yang baik hati kepada sesama, sangat tenang, penyabar, berilmu, beradab, sikapnya terbuka kepada siapapun dan dicintai dan dihormati banyak orang karena tinggi budinya. Keempat, minat sosial (social interest) yang terdapat pada tokoh Gurutta dalam novel Rindu karya Tere Liye adalah Gurutta memiliki rasa peduli kepada sesama, mau membaur dengan orang-orang yang jauh kapasitas keilmuannya dan mudah akrab dengan orang lain. Kelima, gaya hidup (style of life) yang terdapat pada tokoh Gurutta dalam novel Rindu karya Tere Liye yaitu Gurutta sangat sederhana. Dan keenam, kekuatan kreatif self (creatife power of the self) yang terdapat pada tokoh Gurutta dalam novel Rindu karya Tere Liye, Gurutta selalu memiliki ide-ide cemerlang dalam setiap permasalahan yang dihadapinya.
\end{abstract}

\section{Kata kunci: Kepribadian, Psikologi Alfred Adler, Novel Rindu}




\section{PENDAHULUAN}

Karya sastra mengungkapkan bermacam-macam permasalahan kehidupan manusia, di antaranya masalah psikologi, sosiologis, sejarah, agama, dan lain-lain. Karya sastra memberikan kebebasan kepada pengarang untuk mengungkapkan kreativitas imajinasinya, berkaitan dengan permasalahan- permasalahan tersebut. Selain itu, ada pula yang memandang sastra sebagai kreasi seni yang menggunakan bahasa yang indah dan memikat. Dalam hal ini, karya sastra dapat memberikan gambaran tentang kehidupan manusia itu sendiri.

Menurut Pradopo (2007:59)

Sastra merupakan ungkapan pribadi manusia yang berasal dari ide, perasaan, pemikiran, dan suatu bentuk gambaran yang diungkapkan melalui karya sastra.

Berdasarkan bentuknya, karya sastra terdiri atas tiga jenis, yakni puisi, prosa, dan drama. Prosa juga disebut sebagai karya fiksi. Salah satu prosa fiksi adalah novel. Novel merupakan prosa yang panjang, mengandung rangkaian cerita kehidupan tokoh fiksional dengan tokoh-tokoh fiksional di sekelilingnya dengan menonjolkan kepribadian dan sifat setiap tokohnya. Salah satu jenis karya sastra yang menarik untuk dikaji adalah novel. Novel mengandung dua unsur, yakni unsur intrinsik dan ekstrinsik. Unsur ekstrinsik novel yang menarik untuk diteliti adalah unsur psikologi tokoh yang mencakup kepribadian tokoh. Artinya, dengan memusatkan perhatian pada tokohtokoh, penelitian dapat mengungkap gejalagejala psikologis kepribadian tokoh baik yang tersembunyi atau sengaja disembunyikan pengarang. Dengan demikian, bagian yang menarik perhatian penulis dalam pembahasan aspek tokoh adalah tentang cara penggambaran kepribadian tokoh.

Novel yang banyak mengungkapkan sisi kepribadian tokoh utamanya yaitu novel Rindu. Novel Rindu karya Tere Liye terbit pada tahun 2014. Novel tersebut berisi tentang kisah perjalanan jamaah haji Indonesia tahun 1938 dengan menggunakan kapal uap Blitar Holland. Pengarang menceritakan perjalanan jamah haji dengan beberapa tokoh yang memiliki kepribadian dan sifat yang berbeda. Novel tersebut mengajarkan nilai-nilai kepribadian dan pendidikan yang terkandung di dalamnya.

Generasi muda saat ini lebih tertarik dengan media sosial dibandingkan membaca kisah inspiratif seorang tokoh sebagai motivasi belajar. Novel ini memberikan nuansa berbeda dengan menampilkan cerita perjalanan haji yang panjang dan lama di sebuah kapal uap milik Belanda bernama Blitar Holland. Banyaknya pembelajaran dan keadaan psikologi tokoh 
yang terkandung dalam novel tersebut sangat menarik untuk dikaji menggunakan teori psikologi Alfred Adler. Teori tersebut memiliki hubungan erat untuk mengulas lebih lengkap keadaan psikologi individual tokoh utama dalam perjalanan haji yang panjang dan menghadapi berbagai konflik selama di perjalanan. Kendala-kendala yang dialami para tokoh dapat diatasi dengan kondisi psikologi yang baik.

Berdasarkan latar belakang masalah mengenai kajian psikologi Alfred Adler dalam novel Rindu, maka dapat dirumuskan permasalahannya sebagai berikut: (1) Bagaimana perjuangan menuju superior yang dilakukan tokoh utama novel Rindu karya Tere Liye?; (2) Bagaimana pengamatan subjektif terhadap tokoh utama novel Rindu karya Tere Liye?; (3) Bagaimana kesatuan kepribadian tokoh utama novel Rindu karya Tere Liye?; (4) Bagaimana minat sosial tokoh utama novel Rindu karya Tere Liye?; (5) Bagaimana gaya hidup tokoh utama novel Rindu karya Tere Liye?; dan (6) Bagaimana kekuatan kreatif tokoh utama novel Rindu karya Tere Liye? Penelitian ini bertujuan sebagai berikut: (1) mendeskripsikan perjuangan menuju superior yang dilakukan tokoh utama novel Rindu karya Tere Liye, (2) mendeskripsikan pengamatan subjektif terhadap tokoh utama novel Rindu karya Tere Liye, mendeskripsikan kesatuan kepribadian tokoh utama novel Rindu karya Tere Liye, (4) mendeskripsikan minat sosial tokoh utama novel Rindu karya Tere Liye, mendeskripsikan gaya hidup tokoh utama novel Rindu karya Tere Liye, dan (6) mendeskrisikan kekuatan kreatif tokoh utama novel Rindu karya Tere Liye.

\section{KAJIAN TEORI}

\section{Psikologi Individual}

Menurut Alwisol (2010:64)

psikologi individual memandang individu sebagai makhluk yang saling tergantung secara sosial. Perasaan bersatu dengan orang lain (interes sosial) ada sejak manusia dilahirkan dan menjadi syarat utama kesehatan jiwa. Teori psikologi Individual Alfred Adler yang digunakan, meliputi; perjuangan menjadi superior (striving forsuperiority), pengamatan subjektif (subjective perceptions), kesatuan kepribadian (unity of personality), minat sosial (social interest), gaya hidup (style of life), kekuatan kreatif self (creatife power of the self).

\section{Perjuangan Menjadi Superior (Striving Forsuperiority)}

Prinsip pertama dari teori Alfred Adler adalah kekuatan dinamis dibalik perilaku manusia adalah berjuang untuk meraih keberhasilan atau superioritas. Adler mereduksi semua motivasi menjadi satu dorongan tunggal, berjuang untuk meraih 
keberhasilan atau superioritas. Psikologi individual mengajarkan bahwa setiap orang memulai hidup dengan kelemahan fisik yang memunculkan perasaan inferior, perasaan yang memotivasi seseorang untuk berjuang demi meraih superioritas atau keberhasilan. Individu yang tidak sehat secara psikologis akan berjuang untuk superioritas pribadi, sedangkan individu yang sehat secara psikologis mencari keberhasilan untuk semua umat manusia.

Selanjutnya, Adler menyebut kekuatan tunggal itu sebagai berjuang untuk meraih superioritas. Namun, dalam teori terakhirnya, ia membatasi istilah ini pada manusia yang berjuang untuk meraih superioritas pribadi di atas orang lain dan memperkenalkan istilah 'berjuang untuk meraih keberhasilan' yang menggambarkan manusia yang termotivasi oleh minat sosial yang sangat tinggi (Adler, 1956).

\section{Pengamatan Subjektif (Subjective}

\section{Perceptions)}

Prinsip Adler yang kedua adalah persepsi subjektif seseorang membentuk perilaku dan kepribadian mereka. Manusia berjuang untuk meraih keunggulan atau keberhasilan untuk mengganti perasaan inferior. Pengamatan subjektif ini lebih mengarah kepada sikap berpikir maju dan selalu memberikan motivasi dan dapat pula dilakukan pengamatan dari teman atau keluraga.

\section{Kesatuan Kepribadian (Unity of Personality)}

Prinsip ketiga dari teori Adler adalah kepribadian itu menyatu dan selfconsistent. Ketika memilih istilah psikologi individual, Adler berharap untuk menekankan keyakinannya bahwa setiap orang itu unik dan tak terpisahkan. Jadi, psikologi individual menekankan pada kesatuan fundamental dari kepribadian dan gagasan bahwa perilaku yang tidak konsisten itu tidak ada. Pikiran, perasaan, dan tindakan, semuanya mengarah pada satu sasaran dan berfungsi untuk mencapai satu tujuan. Ketika seseorang bersikap tidak teratur atau tidak bisa diprediksi, perilaku mereka memaksa orang lain menjadi defensif dan waspada terhadap tindakan yang tak terduga. Meskipun perilaku mereka kelihatan tidak konsisten, ketika dilihat dari perspektif tujuan akhir, perilaku tersebut terlihat baik. Akan tetapi, ada kemungkinan bahwa perilaku yang mereka tunjukkan merupakan usaha-usaha yang tidak disadari untuk mengecoh dan menempatkan orang lain lebih rendah dari dirinya. Perilaku yang membingungkan dan tampak tidak konsisten ini memberikan orang tersebut keuntungan dalam hubungan interpersonal. Walaupun orang seperti ini sering berhasil dala usahanya untuk mengungguli orang lain, mereka biasanya tetap tidak menyadari motif 
yang mendasari perilaku mereka dan tetap bersikeras menolak setiap gagasan bahwa mereka berhasrat meraih keunggulan di atas orang lain.

Adler (1956) mengenali beberapa cara di mana keseluruhan diri manusia berfungsi dengan kesatuan dan selfconsistency. Cara pertama disebutnya sebagai bahasa organ. Kesatuan kepribadian lebih mengarah kepada sifat dan sikap yang ada pada seseorang yang membentuk satu kesatuan kepribadian orang tersebut.

\section{Minat Sosial (Social Interest)}

Prinsip Adler yang keempat adalah nilai dari semua aktivitas manusia harus dilihat dari sudut pandang minat sosial. Minat sosial (Social Interest) adalah terjemahan Adler, yang sedikit menyesatkan, dari istilah Jerman yang asli, yaitu Gemeinschaftsgefühl. Terjemahan yang lebih baik bisa jadi "perasaan sosial" atau "perasaan berkomunikasi”, tetapi

Gemeinschaftsgefühl sebenarnya mempunyai makna yang tidak bisa diekspresikan secara penuh dalam kata atau frasa bahasa Inggris. Kira-kira maknanya adalah perasaan menjadi satu dengan umat manusia; menyatakan secara tidak langsung keanggotaan dalam komunitas sosial seluruh manusia.

Minat sosial bisa didefinisikan sebagai sikap keterkaitan dengan umat manusia secara umum maupun sebagai sikap keterikatan dengan umat manusia secara umum maupun sebagai empati untuk setiap anggota masyarakat. Minat sosial adalah kondisi alamiah dari manusia dan bahan perekat yang mengikat masyarakat bersamasama (Adler, 1967). Inferioritas alamiah dari manusia menyebabkan mereka mengikatkan diri bersama-sama untuk membentuk masyarakat. Tanpa perlindungan dari keluarga atau suku, nenek moyang kita tertentu sudah dibinasakan oleh bintang yang lebih kuat, lebih buas, dan yang mempunyai indra lebih tajam. Oleh karena itu, miant sosial adalah suatu keharusan untuk melestarikan umat manusia.

\section{Gaya Hidup (Style Of Life)}

Prinsip Adler yang kelima adalah struktur kepribadian yang self-consistent berkembang menjadi gaya hidup seseorang. Gaya hidup (style of life) adalah istilah yang digunakan Alder untuk menunjukkan selera hidup seseorang. Gaya hidup mencakup tujuan seseorang, konsep diri, perasaan terhadap orang lain, dan sikap terhadap dunia. Gaya hidup adalah hasil interaksi antara keturunan atau bawaan lahir, lingkungan, dan daya kreatif yang dimiliki seseorang.

Gaya hidup seseorang terbentuk dengan cukup baik ketika mencapai umur empat atau lima tahun. Setelah masa tersebut, semua tindakan kita berputar disekitar gaya hidup kita yang sudah 
terbentuk itu. Manusia dengan gaya hidup yang sehat dan bermanfaat secara sosial menunjukkan minat sosial mereka melalui tindakan. Adler (1956) percaya bahwa manusia dengan gaya hidup yang bermanfaat secara sosial memperlihatkan bentuk kemanusiaan yang paling tinggi dalam proses evolusi dan bentuk ini sangat mungkin memenuhi dunia di masa depan (Jess Feist, teori kepribadian hal 91-92).

\section{Kekuatan Kreatif Self (Creatife Power Of} The Self)

Prinsip terakhir dari teori Adler adalah gaya hidup dibentuk oleh daya kreatif yang ada dalam diri manusia. Adler percaya bahwa setiap orang memiliki kebebasan untuk menciptakan gaya hidupnya sendiri. Pada akhirnya, setiap orang bertanggung jawab akan dirinya sendiri dan bagaimana mereka berperilaku. Daya kreatif (creative power) yang mereka miliki membuat mereka mengendalikan kehidupan mereka sendiri, bertanggung jaawab akan tujuan akhir mereka, menentukan cara yang mereka pakai untuk meraih tujuan tersebut, dan berperan dalam membentuk minat sosial mereka.

Daya kreatif adalah konsep yang menggambarkan pergerakan (movement), dan pergerakan ini adalah karakteristik hidup yang paling penting. Adler (1956) menjelaskan pentingnya keturunan dan lingkungan dalam membentuk kepribadian.
Kecuali kembar identik, setipa anak terlahir dengan susunan genetik yang unik dan segera sampai pada pengalaman sosial yang berbeda dengan manusia lain.

\section{METODOLOGI PENELITIAN}

Metode penelitian yang digunakan dalam penelitian ini adalah deskriptif kualitatif. Data dalam penelitian ini adalah kata-kata, kalimat, dan kutipan yang terdapat dalam novel Rindu. Sedangkan, sumber data dalam penelitian ini adalah novel Rindu karya Tere Liye yang diterbitkan oleh Republika Penerbit pada tahun 2014 sebanyak 544 lembar. Teknik pengumpulan data pada novel yang digunakan dalam penelitian ini adalah teknik baca dan catat.

\section{HASIL DAN PEMBAHASAN}

Hasil penelitian terhadap novel Rindu karya Tere Liye terdapat psikologi tokoh yang mencakup kepribadian tokoh utama. Ada enam kepribadian yang terdapat pada tokoh Ahmad Karaeng atau Gurutta yaitu perjuangan menjadi superior, pengamatan subjektif, kesatuan kepribadian, minat sosial, gaya hidup, dan kekuatan kreatif.

\section{Perjuangan menjadi superior (striving for superiority)}

Perjuangan menjadi superior (striving for superiority) yang terdapat dalam novel Rindu karya Tere Liye pada tokoh 
BAHTERA INDONESIA:

ISSN 2541-3252

Jurnal Penelitian Pendidikan Bahasa dan Sastra Indonesia

Vol. 4, No. 1, Mar. 2019

Gurutta adalah Perjuangan Gurutta dalam menggapai

cita-citanya

dengan

memanfaatkan masa mudanya untuk belajar agama. Gurutta mulai belajar di pesantren yang ada di Aceh sampai ke negeri Yaman. Hal ini terdapat dalam kutipan di bawah ini:

Di masa muda, Gurutta pernah belajar agama di Aceh,. Lantas melanjutkan hingga Yaman dan Damaskus, mengkaji agama dari ahli tafsir dan pakar hadis terkemuka. Ia juga pernah menetap di Eropa dua tahun lamanya. Ia benar-benar memahami nasihat 'keajarlah ilmu hingga ke negeri China'. Usai empat puluh lima barulah Gurutta kembali ke Makassar, menjadi imam Masjid Katangka (Liye, 2014: 19).

\section{Pengamatan subjektif (subjective perceptions)}

Pengamatan subjektif (subjective perceptions) yang terdapat dalam novel Rindu karya Tere Liye pada tokoh Gurutta adalah Gurutta selalu dapat menasihati dan memberikan motivasi kepada orang lain. Menurut pengamatan orang-orang di sekelilingnya, Gurutta adalah seorang ulama yang terkenal di Makassar, beradab, berilmu, dihormati, dan dicintai banyak orang karena tinggi budinya. Hal ini terdapat dalam kutipan di bawah ini:

Mijn vriend, kau tidak tahu dia? Orang ini terkenal sekali di seluruh
Makassar. Kapten Phillips bahkan meminta seluruh kelasi memastikan dia dilayani dengan baik. Kau seharusnya menyambutnya dengan baik (Liye, 2014: 97).

\section{Kesatuan kepribadian (unity of personality)}

Kesatuan kepribadian (unity of personality) yang terdapat dalam novel Rindu karya Tere Liye pada tokoh Gurutta adalah kesatuan kepribadian yang dimiliki Gurutta yang baik hati kepada sesama. Hal ini terdapat dalam kutipan di bawah ini:

Tentu tidak, Insya Allah akan kusebut namamu di sana, Dale. Semoga besok lusa kau dan keluargamu bisa berangkat ke Tanah Suci." Gurutta mengangguk, menatap wajah tukang cukurnya dari cermin (Liye, 2014: 17).

Kesatuan kepribadian yang kedua dalam tokoh Gurutta adalah Gurutta sangat tenang dan sabar ketika menghadapai berbagai masalah. Hal ini terdapat dalam kutipan di bawah ini:

Itu hanya pengajian, membahas tentang nasihat agama. Tidak ada paham terlaranng di sana. Kecuali jika kompeni punya definisi baru soal baik-buruk sebuah paham. Wajah tua Gurutta tetap tenang dan sabar, meski komandan itu erseru-seru hingga ludahnya terciprat kemana-mana (Liye, 2014: 37).

Kesatuan kepribadian yang ketiga dalam tokoh Gurutta, seorang yang 
berilmu dan beradab. Melalui ilmu yang dimilikinya, ia selalu memberikan nasihatnasihat bijak kepada orang-orang yang ada di kapal. Gurutta juga menyapa Mbah Kakung dengan baik, jamaah haji yang usianya di atas usia Gurutta. Ia tahu bagaimana caranya bersikap kepada orang yang lebih tua darinya. Hal ini terdapat dalam kutipan di bawah ini:

Maka jangan pernah merusak diri sendiri. Kita boleh jadi benci atas kehidupan ini. Boleh kecewa. Boleh marah. Tapi ingatlah nasihat lama, 'tidak pernah ada pelaut yang merusak kapalnya sendiri'. Akan dia rawat kapalnya, hingga dia bisa tiba di pelabuhan terakhir. Maka jangan rusak kapal kehidupan milik kau, Ambo, hingga ia tiba di dermaga terakhirnya (Rindu: 284) dan Apa kabar, Kang Mas? Gurutta bertanya lembut (Liye, 2014: 468).

Kesatuan kepribadian yang keempat dalam tokoh Gurutta, seorang yang sikapnya terbuka kepada siapapun. Gurutta sempat menceritakan tentang masa mudanya kepada salah satu kelasi kapal yang bernama Ambo Uleng. Hal ini terdapat dalam kutipan di bawah ini:

Gurutta tersenyum takzim. Ia jarang sekali menceritakan masa mudanya. Hanya orang terdekat yang tahu. Tapi menatap wajah ingin tahu Ambo Uleng malam ini, cahaya matanya yang berharap menemukan jawaban, Gurutta memutuskan menceritakannya (Liye, 2014: 401).

Kesatuan kepribadian yang kelima dalam tokoh Gurutta, seorang yang dicintai dan dihormati banyak orang karena tinggi budinya. Hal ini terdapat dalam kutipan di bawah ini:

Kantin lengang, semua orang memerhatikan ke tengah kantin. Dengan memilih Gurutta yang bicara kepada penumpang, Kapten Phillips telah bertindak bijak dalam urusan ini. Gurutta adalah orang yang paling dihormati di Kapal Blitar Holland. Semua orang patuh pada kalimatnya (Liye, 2014: 436).

\section{Minat sosial (social interest)}

Minat sosial (social interest) yang terdapat pada tokoh Gurutta dalam novel Rindu karya Tere Liye adalah Gurutta memiliki rasa peduli kepada sesama. Rasa pedulinya kepada penumpang kapal yang membawa anak-anak dengan memberikan ide untuk mengadakan sekolah sementara selama berada di kapal. Hal ini terdapat dalam kutipan di bawah ini:

Kita juga harus memikirkan sekolah anak-anak selama di kapal. Mereka membutuhkan kelas sementara agar saat kembali tidak terlalu tertinggal. Apakah ada yang bisa mengajar pelajaran berhitung, pengetahuan alam, pengetahuan sosial, dan bahasa Belanda? (Liye, 2014: 58). 


\section{Gurutta juga merupakan}

seseorang yang mau membaur dengan orangorang yang jauh kapasitas keilmuannya dan mudah akrab dengan orang lain. Gurutta mengenal dan mau membaur dengan seorang tukang cukur. Hal ini terdapat dalam kutipan di bawah ini:

Itu segalanya, Gurutta. Itu melebihi apapun. Berbaris orang-orang ingin bersalaman dengan Gurutta setiap pekan di Masjid Katangka. Hari ini, kalau mau jujur, sungguh aku seperti bermimpi ketika Gurutta masuk ke tempat cukur yang sederhana ini. Dan sekarang lihatlah, Gurutta hendak menyebut namaku juga di Mekah sana. Dale menyeka ujung matanya yang basah (Liye, 2014: 17).

Gurutta juga akrab dengan kelasi-kelasi kapal seperti Ambo Uleng dan Ruben, penumpang, seperti keluarga Daeng Andipati, Mbah Kakung dan Mbah Putri, Bonda Upe dan suaminya, serta orang-orang Belanda seperti Kapten Phillips, Chef Larss, dan lain sebagainya.

\section{Gaya hidup (style of life)}

Gaya hidup (style of life) yang terdapat pada tokoh Gurutta dalam novel Rindu karya Tere Liye, Gaya hidup yang dijalani Gurutta sangat sederhana. Sejak masih muda hingga menjadi ulama, Gurutta selalu rendah hati dan penyabar. Saat ditinggal kekasihnya meninggal, ia tetap sabar dan ikhlas sehingga ia dipertemukan dengan wanita lain oleh Allah dan hidup bahagia bersama anak-anaknya. Gurutta juga memegang tegung ajaran agamanya.

\section{Kekuatan kreatif self (creatife power of the self)}

Kekuatan kreatif self (creatife power of the self) yang terdapat pada tokoh Gurutta dalam novel Rindu karya Tere Liye, Gurutta selalu memiliki ide-ide cemerlang dalam setiap permasalahan yang dihadapinya. Gurutta memberikan arahan kepada keluarga yang membawa anak-anak untuk diadakan pelajaran mengaji setiap sore setelah ashar dan mendirikan sekolah sementara bagi anak-anak di kapal tersebut. Hal ini terdapat dalam kutipan di bawah ini:

Ada lima keluarga yang membawa anak-anak." Gurutta menghitung, mengangguk," ditambahkan penumpang yang naik di pelabuhan berikutnya, jumlahnya bisa bekasan atau puluhan. Baik inilah yang sedang kupikirkan. Setiap sore setelah ashar, kita mungkin bisa mengadakan pelajaran mengaji untuk mereka. Agar mereka memiliki kegiatan bermanfaat selama di kapal (Liye, 2014: 56).

Sepertinya itu ide yang sangat baik, Gurutta.” Bapak Soerjaningrat berkata santun. Aku tidak keberatan, Aku bisa 
mengajar bahasa Belanda dan berhitung (Liye, 2014: 143).

Selain itu, Gurutta juga memanfaatkan waktu selama di kapal dengan menulis sebuah buku sehingga setelah sampai di Mekah, ia dapat menyelesaikan satu atau dua buku sekaligus.

\section{SIMPULAN}

Berdasarkan hasil penelitian yang telah dilakukan mengenai kajian psikologi Alfred Adler dalam novel Rindu karya Tere Liye dapat disimpulkan bahwa melalui kajian psikologi Alfred Adler terdapat enam teori kepribadian pada tokoh utama yaitu tokoh Ahmad Karaeng atau Gurutta. Pertama, Perjuangan menjadi superior (striving for superiority) yang terdapat pada tokoh Gurutta dalam novel Rindu karya Tere Liye, meliputi perjuangan Gurutta dalam menggapai cita-citanya dengan memanfaatkan masa mudanya untuk belajar agama di Aceh dan Yaman. Kedua, pengamatan subjektif (subjective perceptions) yang terdapat pada tokoh Gurutta dalam novel Rindu karya Tere Liye adalah Gurutta selalu dapat menasihati dan memberikan motivasi kepada orang lain. Menurut pengamatan orang-orang di sekelilingnya, Gurutta adalah seorang ulama yang terkenal di Makassar, beradab, berilmu, dihormati, dan dicintai banyak orang karena tinggi budinya. Ketiga, kesatuan kepribadian (unity of personality) yang terdapat pada
Liye adalah kesatuan kepribadian yang dimiliki Gurutta yang baik hati kepada sesama, sangat tenang, penyabar, berilmu, beradab, sikapnya terbuka kepada siapapun dan dicintai dan dihormati banyak orang karena tinggi budinya. Keempat, minat sosial (social interest) yang terdapat pada tokoh Gurutta dalam novel Rindu karya Tere Liye adalah Gurutta memiliki rasa peduli kepada sesama, mau membaur dengan orang-orang yang jauh kapasitas keilmuannya dan mudah akrab dengan orang lain. Kelima, gaya hidup (style of life) yang terdapat pada tokoh Gurutta dalam novel Rindu karya Tere Liye, Gaya hidup yang dijalani Gurutta sangat sederhana. Dan keenam, kekuatan kreatif self (creatife power of the self) yang terdapat pada tokoh Gurutta dalam novel Rindu karya Tere Liye, Gurutta selalu memiliki ide-ide cemerlang dalam setiap permasalahan yang dihadapinya.

\section{DAFTAR PUSTAKA}

Alwisol. 2010. Psikologi Kepribadian. Malang: UMM Press.

Pradopo, Rachmat Djoko. 2007. Beberapa Teori Sastra, Metode Kritik, dan Penerapannya. Yogyakarta: Pustaka Pelajar. 
BAHTERA INDONESIA:

ISSN 2541-3252

Jurnal Penelitian Pendidikan Bahasa dan Sastra Indonesia

Vol. 4, No. 1, Mar. 2019

Liye, Tere. 2014. Rindu. Jakarta: Republika Adler, Alfred. 1930. Individual Psychology. Penerbit.

Worcester Mass. Clark Univ Press.

Adler, Alfred. 1956. The Origin of The

Neurotic Disposition. In H. L. Ansbacher, \& R. R. Ansbacher,

Nurgiyantoro, Burhan. 2013. Teori The Individual Psychology of Pengkajian Fiksi. Yogyakarta: Alfred Adler. New York: Basic Gadjah Mada University Press. Books, Inc. 